\title{
IS PORTUGAL REALLY SO ARTERIOSCLEROTIC? RESULTS FROM A CROSS-COUNTRY ANALYSIS OF LABOR ADJUSTMENT
}

\author{
John T. Addison* and Paulino Teixeira**
}

\author{
* Department of Economics, University of South Carolina (U.S.A.), and University of \\ Birmingham (U.K.) \\ ** Faculdade de Economia, Universidade de Coimbra (Portugal), and Center for \\ European Economic Research (ZEW), Mannheim, Germany
}

\begin{abstract}
Reputation indexes of employment protection have proven popular constructs in studies of the covariation of labor market institutions and macroeconomic outcomes. Portugal occupies an unenviable rank order in such measures of the stringency of employment protection. We critique this reputation in two ways: first, by offering a modicum of 'corrective' institutional detail on the nature of employment protection in Portugal; and, second, and more substantively, by offering a detailed analysis of the process of labor adjustment in Portugal, benchmarked to other-country experience. The latter exercise - based on a two- and one-stage error correction model - reveals Portugal to have a very high speed of adjustment to deviations from the long-run employment-output equilibrium - a result that is clearly at odds with its allegedly sclerotic labor market. More in accord with received wisdom is the very smooth labor adjustment mechanism characterizing the United Kingdom. The most notable feature of the German results is the deterioration in that country's speed of adjustment in recent years. The Spanish case is distinguished by its erratic path of long-run adjustment.
\end{abstract}

We thank, without implicating, Martin Falk and Viktor Steiner for helpful comments. 


\section{Introduction}

There is a seeming contradiction between its alleged reputation as one of the most rigid labor markets in OECD-Europe and the apparent ability of the Portuguese economy to accommodate to changes in output demand during the last two decades. In addition, and despite a continuous increase in labor force participation, especially among women, the country has evinced remarkably low unemployment (averaging 5.8 percent over the last decade). [1]

Portugal is reported to be a near exemplar of arteriosclerosis in two key references in the literature. First, in assessing the strictness of dismissals protection legislation along the dimensions of procedural delays, notice and severance pay, and definition of unfair dismissal, Grubb and Wells (1993, Table 1.3) rank Portugal in first position, tied with Spain, in their 11country sample. (The other countries considered here, Germany and the United Kingdom, ranked fifth and eleventh, respectively.) Widening the definition to include, in addition to dismissals protection, limitations on fixed-term contracts and restrictions on overtime, and flexible weekend and night work confirms Portugal's number one position, while modestly improving Spain's ranking to third - and leaving unchanged the rankings of Germany and the U.K. (Grubb and Wells, 1993, Table 9.1). Second, the OECD Jobs Study (1995, Table 6.7, panel B) provides scant relief: Portugal is now ranked second behind Italy in terms of the rigidity of its employment protection legislation (Germany deteriorates somewhat on this scoring, Spain improves modestly, and the position of the U.K. as the most flexible nation is again confirmed.)

These rankings, while not uncontested [2], have exhibited considerable "path dependence" in the literature, having been used in a variety of studies to measure the contribution of employment protection to such macoeconomic outcomes as unemployment, employment, and nonemployment (e.g. Scarpetta, 1996; Nickell, 1997). But it is our contention that such measures are arbitrary in general and often factually incorrect in the 
specifics - based on a misreading of the law in the Portuguese case. Although we will illustrate the imprecision that arises in the construction of such regulatory indexes by reference to Portugal, our main concern is to examine labor market flexibility by looking to outcomes: net employment and output flows. Based on aggregate data, we derive an indication of labor market flexibility by investigating the adjustment process of labor demand following a permanent increase in output.

There are several advantages of this alternative approach. First, and most obviously, it avoids arbitrary interpretations of often subtle legal statements and assessment of actual enforcement procedures. Second, our focus on the employment outcome rather than unemployment side-steps difficulties of cross-country differences in measurement that continue to dog even so-called "standardized" measures, as well as the theoretical ambiguity of the unemployment rate as an indicator of labor market performance (Blanchard and Portugal, 1998).

It is of course widely accepted that employment protection legislation impacts the ability of the firm to respond to fluctuations in product demand, because of the constraints imposed on hiring and firing labor (the arguments are well rehearsed in Hamermesh, 1988, 1993). In these circumstances, it would be no small surprise if a country with a reputation of rigidity were consistently to display flexibility in reacting to changes in demand conditions. The extant cross-country evidence on speed of adjustment seems to be broadly supportive of the theoretical priors. Let us illustrate by taking one of the most prominent stylized facts: the high speed of adjustment of labor demand in the United States. Studies by Hamermesh (1988), and by Abraham and Houseman $(1993,1994)$ confirm that employment adjustment in the United States is substantially higher than in Europe (and Japan). That being said, differences between the United States and other countries in the adjustment of hours appears altogether less pronounced, possibly because of (subsidized) short-time working (Van Audenrode, 1994), and there is little indication of an increased responsiveness of employment 
adjustment following interludes of labor market liberalization (e.g. Kraft, 1993). However, the suggestion of a reduced speed of employment adjustment in the United States attendant upon the erosion of the hire-at-will common law doctrine in that country is more supportive (Hamermesh, 1993). Clearly, the devil is in the detail.

Although the cross-country evidence is broadly consistent with the theoretical prediction that higher adjustment costs will reduce the speed of adjustment of employment behind output, the extant literature relies on ad hoc estimation techniques: the estimated parameters are obtained from OLS regressions on levels of clearly nonstationary variables, or by simply running the labor demand model in first differences. In the light of recent developments in time-series analysis, especially those pertaining to unit roots and cointegration, the result is that these familiar results lack proper parameterization and that some reassessment is needed. By looking in some detail at Portuguese manufacturing data and effecting a comparison with Gemany, Spain, and the U.K., we seek to advance the labor adjustment discussion by providing better estimates and offering some insight into the vexed question of the covariation of institutions and labor market outcomes.

The plan of the paper is as follows. First we provide a modicum of detail on employment protection rules obtaining in Portugal so as to illustrate the caution required in fixing the notion of rigidity. Second, we briefly address the manufacturing data, 1977:11997:4, and outline the empirical model. Third, our findings are presented along the dimensions of the time-series properties of the variables, the static cointegrating regression model, and labor market dynamics. The threads of the preceding arguments are drawn together in a concluding section.

\section{Institutional Detail (Portuguese Labor Legislation)}

Roughly half-way through our sample period, a number of changes were introduced into Portuguese labor law under the 1989 Law on Dismissals (Lei dos Despedimentos). A 
hallmark of this controversial legislation was the freedom given employers to dismiss individual workers for demand-related reasons. Prior to 1989, and after 1975, individual dismissals were permitted only on disciplinary grounds.[3] Yet this change in the law was less substantive than might appear at first blush. This is because collective dismissals have never been precluded in Portugal, and the threshold size defining a collective dismissal (currently, 2 to 5 employees according to establishment size) is low by international standards.

The pre-1989 prohibition on individual dismissals - for other than disciplinary reasons - has also to be considered alongside legislation on fixed-term contracts. Such regulations were explicitly designed to add a degree of freedom to firm labor input decisions, and they were introduced in 1976 on the heels of legislation that prohibited individual dismissals. The new law on fixed-term contracts (Decree-Law 781/76, Lei dos Contratos a Prazo) allowed firms to hire "temporary" workers almost without restriction. In particular, there was no obligation on the employer to provide any specific justification for entering into such a contractual relationship, and neither severance pay nor notice was required at expiry. In practice, a worker could stay with the firm up to 3 years; and even at the end of this interval it was not difficult to circumvent the spirit of the law through renewals for a further 3 years. The 1989 Lei dos Despedimentos did make some changes to the status quo ante in that firms were now required to meet certain conditions before entering into such arrangements. Specifically, it established eight statutory reasons for concluding of a fixed-term contract. Fixed-term working arrangements which failed to negotiate these statutory gateways would automatically be converted into open-ended contracts. Yet, as a practical matter, the new rules do not seem to have been strictly enforced. And no change in firm behavior in their recourse to fixed-term contracts can be discerned in a before-and-after comparison of fixed-term contract usage (Teixeira, 1998). 
How does this characterization of Portuguese law fit the stylized representation of Portugal as filtered through the standard ranking exercises with which we began our discussion? First of all, the focus on individual dismissals in the construction of that index while understandable in allowing analysts to construct a consistent measure across nations, may be of very limited relevance to labor adjustment; collective rather than individual dismissals may dominate. Second of all, the Grubb-Wells index lacks any appreciation of the application of the law. While ruling on economic matters, the courts have in practice not sought to challenge management prerogative; that is, the economic reasons supplied by the firm will have a fair chance of being accepted by the Portuguese courts in event of litigation. In consequence, firms may not see labor laws pertaining to dismissals protection as a real threat to their competitiveness. This is what we believe underpins the very different results contained in the EC Survey of Employers, noted earlier. Presumably, we may need to look a little more carefully at what firms say they do, even if our main interest lies in devining what they actually do.

The problem is only compounded when one combines indexes containing regulations covering dismissals, hours of work, fixed term contracts, temporary work agencies, and the like. Though this is a laudable attempt to capture the entire regulatory climate, it seems doomed to failure.

If we can agree that any appraisal of the law has to be set in a wider context than any individual piece of legislation, while admitting that this is particularly difficult to do in the sense of the overall regulatory climate (other than perhaps in making broad comparisons between say the United States and Europe) what is the appropriate context? One candidate is of course the collective bargaining system, not least because the impact of employment protection mandates can be mitigated by concessions made under collective bargaining - the tradeoff point. Some remarks on the Portuguese collective bargaining system are particularly germane in this regard. 
First of all, Portuguese real wage development would appear to have been modest for more than two decades. Trade unions have generally been unable to secure significant real wage gains, partly as a result of tripartite regulation/co-ordination involving the government, one of the two competing trade union confederations, and employer side. In this framework, the "social partners" set the annual wage target for wage increases, leaving little room for manoever for negotiations between firms and workers at lower (sectoral and firm) levels. In consequence, as we have indicated, real wage development has been very modest and stable across manufacturing sectors (Teixeira, 1999). [4] Another important factor in this development has been the leading role of the growing public administration sector (accounting for more than 15 percent of total employment) which has tended to set the pattern.

A final collective bargaining issue is the competition between rival worker organizations. This schism has been exploited by successive governments to secure moderate wage development. Of advantage to the government in this regard has been the rules governing worker representation in collective bargaining. Indeed, as rival unions have seldom agreed on whom should be the elected members to bargain with employers, the government has been accused in many instances of promoting negotiations with weaker unions, and then using the extension mechanism (Portarias de Extensão) to apply to all workers an agreement that was ultimately reached with representatives of a tiny minority of workers. This system of "parallel unionism" implies that employers can select (at sectoral and firm level) which union they wish to negotiate with. If, at sectoral or firm level, a given union refuses to accept the extension of a collective agreement that was negotiated with a rival union, the result is that no collective agreement will apply to the workers in question. This may be the worst of all scenarios for workers, who will then be covered by the less favorable general law covering wages and working conditions. The union position is that the government has also threatened to legislate in areas that unions fail to agree on. On net, these elements combine to produce 
weaker collective bargaining than in other European nations and especially in neighboring Spain.

\section{Data and Methodology}

We focus on manufacturing mainly for reasons of data availability. An alternative would be to include the service sector, but the usual statistical sources do not distinguish the business service sector from public services. Given that employment in the latter is often subject to different job security rules, adding in services would be hazardous. Needless to say, the economic literature covering the manufacturing sector is also much more abundant, which means that we can more easily check our results.

Our sample period is $1977: 1$ to $1997: 4$. Data for the U.K. and Spain were obtained from the OECD Main Economic Indicators database (quarterly series). Data for Portugal were collected from the Portuguese Statistical Office (INE) and from the Department of Statistics of the Portuguese Ministry of Labor. For Germany (West Germany), the main data source was the OECD database (for the period 1977-1994), supplemented with information from the Federal Statistical Office (1994 to 1997). Complete information on data sources and definition of the variables is provided in the Appendix. [5]

As noted earlier, our intention is to assess labor market flexibility by observing how firms adjust their labor demand to changes in output and factor prices. The presumption is that, in an event of an exogenous demand shock, and everything else remaining constant, higher flexibility should be manifested in a higher speed of adjustment of labor demand to the desired (long-run) equilibrium.

Although we could restrict our focus to a single country - Portugal in the present case - we found it very useful to conduct the exercise by looking at other countries that might serve as a benchmark. The additional countries are the U.K., Germany, and Spain. The U.K. is widely depicted as the most flexible labor market in Europe, while Germany is viewed as 
having a powerful collective bargaining system. The case of Spain, a neighboring economy, is of prime interest because its similar labor market institutions have produced remarkably different labor market outcomes. Indeed, this diversity has spawned a growing comparative literature (see, inter al., Blanchard and Jimeno, 1995; Bover, Garcia-Perea, and Portugal, 1997; Castillo, Dolado and Jimeno, 1998; Marinon and Zilibotti, 1998).

Our main concern is labor demand and labor demand elasticities, and how these parameters impact a firm's behavior following a given change in output. Firms in this framework are assumed to minimize total costs of production, taking output and factor prices as exogenous variables. Employment is exclusively determined by the demand side of the market.

There is little controversy in the profession about the short-run effects of labor regulations on labor adjustment: under strict employment protection regulations firms are unable quickly to adjust to unexpected shocks in demand. In the long run, however, different strategies can be followed by firms and the result is a much weaker link between the level of labor protection and employment (e.g. Bentolila and Bertola, 1990; Bertola, 1991; Bentolila and Saint-Paul, 1994; Saint-Paul, 1995).

A high speed of adjustment implies that resources can be reallocated between sectors more easily, meaning that workers are out of job for shorter periods of time, and inefficient firms are replaced by more efficient ones so that workers will ultimately benefit from higher wages. It is our contention that a high speed of adjustment to deviations from the long-run employment-output equilibrium is unlikely to be observed in regimes with stringent employment protection rules.

Formally, we will follow the Engle-Granger framework to study the employmentoutput relation. We will therefore first discuss the time-series properties of the labor demand variables, then estimate the long-run elasticities, and finally deploy an the error correction model to evaluate how firms react to deviations from the long-run equilibrium. 
Although the short time span examined here serves to make unit root tests less powerful, we would maintain that cointegrating techniques and implied long-run relationships have appeal from the perspective of standard microeconomic theory; that is, where equilibrium factor demand functions assume the usual form in the levels of the variables. Here the Engle-Granger approach has the advantage of discussing labor adjustment in a framework wherein microeconomic equilibrium theory is explicitly taken into account. At the same time, the derived long-run output and factor price elasticities can then be confronted with other pieces of evidence as further check on the robustness of the estimated results.

According to standard microeconomic theory, there exists a labor demand function relating the levels of employment, output, and factor prices which can be derived from the cost function of a representative cost minimizing firm. An immediate implication of this proposition is that the variables need to be cointegrated; otherwise, the parameters of the estimated labor demand function will be without meaning. Unit root and cointegrating tests thus provide a direct test of equilibrium microeconomic theory: if the series do not survive the tests of stationarity and/or there is no cointegrating vector linking the included variables, one has to conclude that firms either are not rational or that the theory does not pass muster.

[Table 1 near here]

Table 1 shows the evolution of the key variables in all four countries in the sample. Over the two-decade interval, Portugal shows the strongest output growth and the lowest real wage increase. Portuguese employment is unchanged, while Spain records a loss of almost eight hundred thousand manufacturing jobs. The U.K., which evinces the highest increase in real wages of all four countries, has the worst performance in terms of job destruction: more than 2.8 million manufacturing jobs were lost between 1977 and 1997. Germany shows the second poorest employment performance in manufacturing, with approximately 1.7 million jobs lost during the 1990s. Growth in output per worker is higher in Spain. 


\section{Findings}

\section{Unit Root Tests}

The results of the unit root tests on the levels of the variables are presented in Table 2. To determine the number of lags, $\mathrm{k}$, in the estimating equation, we follow Perron (1989). He suggests starting at lag $\bar{k} \mathbf{\nabla} 12$ and then working backward, choosing $k \mathbf{O} \bar{k}$ such that the $\mathrm{t}-$ statistic on lag $\mathrm{k}$ in the $\mathrm{ADF}$ equation is greater than 1.6 (in absolute value) and the t-statistic on lag $l \circledast k$ is less than 1.6. In all cases, the implied $F(4, T)$ statistic - which tests for the presence of (fourth order) serial correlation in the residuals - does not reject the null hypothesis of no serial correlation. In confirmation of previous findings, none of our series rejects the null of no stationarity. The critical value at $5 \%$ is -3.45 and the highest $t_{A D F}$ (in absolute value) is 3.32. In other words, the ADF test cannot reject the hypothesis of the variables being integrated of order 1 .

\section{[Table 2 near here]}

Given the problems of uncertainty about the unit root - the unit root is the limit case of typically high autoregressive series - we have also computed the 90 percent confidence intervals for the largest autoregressive root, $\square$, after Stock (1991). Note that the reported asymptotic intervals for $\square$ differ from the standard $4_{2} \exists$ interval, because when $\square$ is large (nearly one), the confidence interval is discontinous thereby precluding the standard interval construction.

The computed intervals are very wide, containing values substantially different from one. But none of them excludes the unit root, a pattern that has been found in other studies; Stock (1991), for example, reports identical interval width for 14 U.S. macroeconomic series. Based on these intervals, one cannot reject the results obtained from the ADF tests.

To complement this analysis of the properties of the individual series, we also applied the procedure described by Zivot and Andrews (1992); that is, we test the null of a unit root 
against the alternative of a trend-stationary series with a single and endogenous breakpoint. The issue here is whether the unit roots detected in Table 2 are being produced by regime shifts in the data. This issue has been subject of some controversy since Perron (1989) argued that most US macroeconomic series reject the null of no stationarity if a break in the trend function is allowed for. (In Perron, 1989, under the alternative hypothesis the series are trend stationary with one exogenous break in the data).

The test for a single and unknown structural break amounts to introducing level-shift and slope-shift dummies in the ADF-type testing equation (respectively defined as $D U_{t} \boldsymbol{\nabla} 0$, if $t \mathrm{O}_{B}$, and $D U_{t}=1$ otherwise, and $D T_{t} \boldsymbol{\nabla} t T_{B}$, if $t \odot T_{B}$, and $D T_{t}=0$ otherwise) and selecting the unknown breakpoint parameter $T_{B}\left(2 \mathbf{O}_{B} \mathbf{O} T\right)$ such that the $t_{\square}$ (i.e. the $\mathrm{t}-$ statistic for testing the presence of a unit root in the series) is minimized. If at $t \boldsymbol{\mathbf { a }} T_{B}, t_{\square}$ is greater than the critical value, the null of the series having a unit root is accepted. According to Table 3, there is confirmation that the series have a unit root, even having allowed for segmented trends in the data.

[Table 3 near here]

\section{The Static Cointegrating Regression}

The general specification models labor demand as a function of output and input prices that are seen as exogenous variables by cost minimizing firms, as follows

$L \mathbf{\mathbf { f }} f(W, Y, R M, E, I N T, U C)$,

where L denotes labor demand and W, E, INT, RM, and UC denote the input prices of labor (real wage), energy, intermediate goods, raw materials, and the user cost of capital (proxied by the producer price index of investment goods purchased by manufacturing firms), respectively. Our preferred specification, derived from (1), is a homogenous of degree zero 
labor demand function in relative prices that also includes a deterministic trend term (T) to control for changes in total factor productivity. Expressed in logs, we have

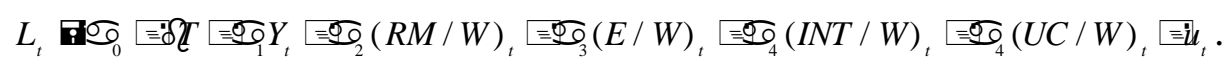

Given the observed high correlation between input prices (always exceeding 0.90) and what seems to be a very marginal role of input prices in labor demand adjustment, we decided to include only one relative price. For Germany, we use the relative price of intermediate inputs, for Portugal and Spain the relative price of energy, and for the U.K. the relative price of raw materials.

From Tables 2 and 3, employment, output, and relative input price variables are not integrated of order zero. We therefore proceed with the first-stage OLS estimation of equation (2) in order to establish cointegration of the variables. The results are presented in Table 4. Besides the widely used ADF cointegrating test, we also present the cointegrating regression Durbin-Watson statistic (CRDW), even though Campbell and Perron (1991) show that the latter should not be used to test the null hypothesis of no cointegration against the alternative of cointegration. In the interest of a preliminary interpretation of the results, it is usually taken as good indication that the variables are cointegrated if the $\mathrm{R}^{2}$ exceeds 0.95 and the CRDW is not too low (the lower bound being 0.25; see, for example, Hendry, 1986). In addition, rejection by the ADF test of the hypothesis that the OLS residuals from (2) are non-stationary provides some indication of the existence of a cointegrating vector and hence of a long-run relationship among the included variables.

\section{[Table 4 near here]}

At first glance, the evidence from Table 4 is not very strong: the CRDW fails to exceed the critical value in one case (Spain), the $\mathrm{R}^{2}$ is lower than 0.95 in three cases, and the ADF test only rejects the null hypothesis of no cointegration in the case of Portugal. To further check these results, we decided to implement the $Z_{a}$ test described by Phillips and Ouliaris (1990); a procedure that, in comparison with the ADF test, has revealed superior 
power properties in Monte Carlo studies (Haug, 1996). This test is performed using the residuals $m_{t}$ from the OLS cointegrating regression (2) to test for their stationarity. The null hypothesis is non-stationarity of the residuals, that is, the variables are not cointegrated. The $\mathrm{Z}_{\alpha}$ test also failed to reject the null of no cointegration, irrespective of the number of estimated autocovariances included in the test, usually four for quarterly data.

Given the low power of these tests (in particular, the problem of substantial size distortions if the variables under consideration are not really $\mathrm{I}(1)$ but have roots close to unity), the hypothesis of no cointegration will be further discussed in the next section by introducing one-stage and two-stage ECM-based tests. Pending this analysis, we briefly comment on the parameters of the static cointegrating regressions reported in Table 4, noting that the t-statistics obtained from a standard OLS run on (2) cannot be applied to construct usual confidence intervals because the variables are I(1) thereby violating the constancy of the variance of the residuals. [6] The parameter estimates can nevertheless be used to derive longrun labor demand elasticities provided that the variables are in expressed in logarithms and cointegrated even if no dynamics are specified in model (2).

As expected, all countries display a statistically significant negative trend in manufacturing employment. Spain and the U.K. (-0.01 in both cases). For Portugal and Germany, the estimated trend is only half this value. Translated into annual rates, the trend coefficients imply annual decreases of $4 \%$ and $2 \%$, respectively, in manufacturing employment of the two groups of countries. Output elasticities of 0.62 for the U.K. and 0.84 for Germany confirm the results of previous studies pointing to increasing returns to scale in manufacturing in these two countries. Thus, for example, Harvey et al. (1986), using a different approach to model labor demand in the British manufacturing sector, report an output elasticity of 0.66 , which is also the output elasticity found by Flaig and Steiner (1989) for Germany. Spain has an output elasticity in the same range (0.74), while Portugal has the lowest output elasticity of all four countries (0.4). Factor price elastiticities are very small 
(less than 0.05) in all countries in the sample other than Spain (0.26). Increases in the relative prices of energy in Portugal and Spain and of raw materials in the U.K. are expected to lower the demand for labor. On the other hand, increases in the relative price of the intermediate input in Germany imply increases in labor demand. In other words, the selected input factors are complementary with labor in Portugal, Spain, and the U.K. and substitutes for labor in Germany.

\section{Labor Demand Dynamics}

The second stage of the Engle-Granger method estimates the labor demand model in first differences. However, and contrary to what is known as the econometric tradition in empirical labor demand (e.g. Hamermesh, 1993, Abraham and Housemann, 1993, and 1994), in the time-series tradition the adjustment equation in first differences takes into account the estimated equilibrium in the levels of the variables. This is achieved by including in the second-stage ECM model an error correction term that gives information on the past errors (i.e. past deviations from the long-run equilibrium).

\section{[Table 5 near here]}

The results of this procedure are given in Table 5, and were obtained using a generalto-simple modelling methodology that starts with a over-parameterized model and ends with a parsimonious specification that keeps as many lags in the model as are necessary to satisfy all diagnostic regression tests. The model is specified as follows

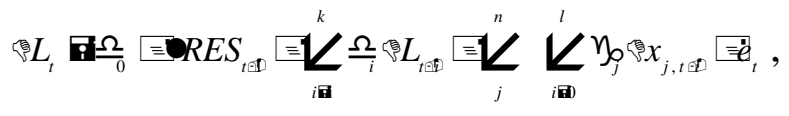

where $R E S_{t}, \mathbf{q} L_{t} t_{t}$ are the OLS residuals from equation (2) and $x_{t}$ denotes the right-handside variables included in the model (namely, output and relative input prices).

A key estimate of model (3) is the error-correction coefficient $\lambda$, indicating how employment reacts to past equilibrium errors, $R E S_{t \in \mathbb{n}}$. Typically, the short-run effects $\eta_{\rho}$ will 
be smaller than the long-run effects $\widetilde{\sigma}_{i}$ (given by the first-stage cointegrating estimation); the standard error of the static regression is higher than that of the $\mathrm{ECM},{ }_{u}^{2}+\bullet_{e}^{2}$; and जी $\square 0$ when the variables are cointegrated. When $\bullet$ : 0 , the variables are not cointegrated. In other words, performing a standard t-test on the error correction coefficient will serve as a cointegrating test, and therefore rejection of the null (that this coefficient is zero) is to be interpreted as rejection of the null of no cointegration (Kremers, Ericsson, and Dolado, 1992). The ECM model not only allows precise short-run parameter estimation, but also provides cointegrating tests (called ECM-based cointegrating tests) that have been shown to have superior power properties than the residual-based tests implemented in the previous section as they do not impose what is known as the common-factor restriction (Kremers, Ericsson, and Dolado, 1992; Banerjee, Dolado, and Mestre, 1992).

Hendry (1986) again provides some intuition on a lower-bound for the critical value, suggesting that a t-statistic for the error correction term $\left(t_{E C M}\right)$ in excess of 3.0 (in absolute value) would be a good indication that the variables included in the static regression (2) are cointegrated. To formally test the hypothesis of no cointegration, we will use Mackinnon's critical values (Davidson and Mackinnon, 1993, Table 20.2), noting that the standard unit root critical values are not valid because the $t_{E C M}$ statistic contains the estimated residuals from the first stage static regression.

Beginning with Hendry's indicative values for $t_{E C M}$, Table 5 provides some evidence of a first-stage cointegrating relationship for Germany, Portugal and the U.K. All countries show $t_{E C M}$ statistics higher (in absolute value) than 3.0 Not surprisingly, given the cointegration regression Durbin-Watson (CRDW) statistic of 0.07 , the hypothesis of cointegration is rejected for Spain, where the t-statistic is distinctly higher than -3. [8] Yet, taking Mackinnon's critical values, Portugal and Germany pass the test (at 0.10 level), but the U.K. with a $t_{E C M}$ of -3.06 definitely does not. Although the one-stage ECM models discussed below 
provide further evidence on cointegration, thus far it seems that for the U.K. and Spain the labor demand variables may not be cointegrated. Bearing these results in mind, our subsequent simulation exercises on the path of labor adjustment will implement the cases of cointegration and of no cointegration (i.e. the model in first differences). For Spain, the simulation will use first differences exclusively.

In any event, a key finding from Table 5 is the seeming slow rate of adjustment to disequilibrium in Germany (amounting to 0.05 or 5 percent per quarter) and the U.K. (10 percent per quarter). The values for Germany are approximately half those reported by Flaig and Steiner (1989) and Belke and Göcke (1997), who obtain error-correction terms equal to 0.12 (in manufacturing) and 0.14 (for the whole economy), respectively. Abraham and Houseman (1994), despite using a different methodology (the standard Koyck model), report a speed of adjustment of employment to changes in output for Germany of approximately the same size: 0.16 . The corresponding estimate for the U.S. is 0.62 . Converted into mean adjustment lags, Abraham and Houseman's estimates represent a mean adjustment lag of 0.6 quarters for the U.S. and 5.1 quarters for Germany. The same computations, now using our estimates of the adjustment process to the long-run relationship in Table 5, will yield a mean adjustment lag of 18.6 quarters for Germany. Given the sample period covered by these three studies - 1964:1-1986:4, 1970:1-1992:3, and 1973:1-1990:4, respectively - there seems to be every indication that labor adjustment in Germany has slowed down in the 1990s. Portugal, for its part, shows a remarkable speed of adjustment, a respectable 52 percent per quarter, which implies a mean lag of 0.9 quarters, not very far from the U.S. response. We would caution, however, that these computations are only indicative because in our model there is no geometric decline in the adjustment process as in the Koyck formulation. As will be made clear in the simulation exercises, below, although the coefficient $\lambda$ provides an indication of how firms react to past deviations from the long-run equilibrium, that parameter by no means exhausts the dynamics of the labor demand because the dynamic adjustment is also reflected 
in the coefficients of the lagged differences included in the model. Nevertheless, the error correcting coefficient in the Portuguese case is remarkable for its magnitude and significance level. All regression statistics included in Table 5 are within the expected range and the lagged differences on employment and output have the expected sign in all cases; the lagged output difference in Portugal being the sole exception.

\section{[Table 6 near here]}

As a test of the error-correction specification in equation (3), Table 6 (OLS columns) presents the results of fitting an ECM model in which no restrictions are imposed in the cointegrating vector. We also report (Table 6, NLS columns) the results of a nonlinear onestage ECM model in which the short- and long-run elasticities are jointly estimated. The former approach serves to test the long-run relationships estimated in the first-stage cointegrating regressions; the latter provides standard errors on the short-run and long-run effects and on the error-correction coefficient. To test the hypothesis that $t_{E C M}$ in this model is statistically different from zero (i.e. that the variables are cointegrated), we will use the critical values reported by Banerjee, Dolado, and Mestre (1992).

[Table 7 near here]

The derived long-run relationships are provided in Table 7. Both the OLS and NLS unrestricted one-stage models largely confirm the cointegrating vectors estimated in the firststage Engle-Granger method, particularly with respect to the output elasticity coefficients. Germany, Portugal, and the U.K. have a long-run output elasticity of 1.0, 0.34, and 0.64, respectively. In Table 3 , the corresponding estimated values were $0.84,0.40$, and 0.62 . In both models, the estimated parameters are highly statistically significant and the short-run elasticities obtained in Table 4 (for the second-stage ECM model) are also largely confirmed. The obvious exception is Spain, which not only displays an extremely high output elasticity (2.2), but also a much higher absolute $t_{E C M}$ statistic in the NLS estimation. Therefore, 
although the error correction coefficient is still very small (-0.058) and the $t_{E C M}(-3.22)$ higher than the Banerjee, Dolado, and Mestre 5 percent critical value of -3.56 (at 10 percent the critical value is -3.22 ), the statistical evidence against cointegration for Spain is less obvious than in the two-stage Engle-Granger approach. If one is not willing to reject no cointegration, the evidence is still that the adjustment process to disequilibrium is very slow in Spain. Overall, and irrespective of the country, the $t_{E C M}$ statistics of the NLS method do not provide strong evidence on cointegration of the labor demand variables, with the principal exception of Portugal and, to a lesser extent, Germany, which meets the critical test value at the .10 level.

We finally address the dynamic adjustment properties of labor demand by simulating the impact on employment of a permanent increase in output. We already mentioned that greater flexibility in the labor market should lead, all else constant, to a higher rate of adjustment of labor to the long-term equilibrium path. Given the methodology followed here, the simulated adjustment path will take into account the short-term dynamics (taken from the ECM model), as well as the estimated long-run equilibrium relationships. Thus, substituting the cointegrating equation into the ECM model, and then expanding the first difference operator, we obtain a dynamic labor demand equation in levels of the variables which allows us to simulate the adjustment path of labor following a permanent 1 percent exogenous change in output demand. In the long-run, the impact on employment is given by the long-run output elasticity, so that the issue is one of whether the countries in our sample are slow or quick to adjust to their long-run equilibrium relationships. The results of this simulation exercise are shown in Figure 1 (a) through (d). Even though the evidence of cointegrating relationships for Germany and the U.K. is not strong, the simulation exercise will use the parameters of the two-stage Engle-Granger method. Results from assuming no cointegration in labor demand - the simple first difference model - show virtually the same pattern of 
adjustment and are not reported here. As noted earlier, the results for Spain were obtained using the simple first-difference model, that is, the parameters in Table 5, column (b). [8]

The U.K. situation, shown in Figure 1 (d), is that employment takes roughly 4 years to fully adjust to its long-term equilibrium level. Harvey et al.(1986), using an employmentoutput equation (with no input prices), find virtually the same adjustment path. One remarkable feature of the U.K. labor demand is the smoothness of the adjustment process. Despite the relatively small error correction coefficient, the impact on employment steadily increases in the first 9 quarters, when it reaches its maximum, and then very quickly tends to the long-run equilibrium. As we will see, none of the remaining countries shows such a wellbehaved adjustment process.

Germany, with a long-run output elasticity of 0.84 in this exercise, is undoubtedly much slower to adjust to exogenous changes in demand. The maximum impact is reached only 15 quarters after the initial shock and then declines before converging to its long-term equilibrium. Even if we concede that changes in labor demand are small after the twentyseventh quarter (or even earlier), there is no question that Germany's adjustment is slower than that of the U.K. These results can again be compared with Flaig and Steiner (1989), who report that a 1 percent increase in output achieves its largest impact after seven quarters and obtains its equilibrium level roughly eighteen quarters later. Their own estimate of the longrun output elasticity is, it will be recalled, 0.66. [9]

Portugal, which has the largest error correcting term of all four countries, shows somewhat more erratic adjustment behavior than either the U.K. or Germany. As in the case of U.K., the peak is achieved very quickly (after seven quarters), labor demand then declines sharply only to increase again and stabilize at its long- term equilibrium level in the seventeenth quarter, with very slight shifts thereafter. It seems therefore that in Portugal the impact on labor demand, although not instantaneous (there is no impact the first quarter), is very responsive in the first two years with its maximum achieved in the sixth quarter, but the 
visible instability along the adjustment process indicates that the labor market functioning may not be as smooth as in the U.K., or even Germany.

Patently, Spain shows the most erratic pattern of all. Initially, there is a very quick response of employment to the exogenous change in demand. The maximum impact is achieved five quarters after the initial shock, with an almost 2 percent increase in labor demand. What then follows is a sequence of decreasing ups and downs that stabilize after the twenty-fifth quarter. We interpret this result as an indication that Spain is still probably facing the toughest challenges when it comes to adjust manufacturing employment to changes in demand conditions.

\section{Conclusions}

There is clearly room for some reassessment of the main characteristics of the Portuguese system of employment protection. We have seen that the two most influential "reputation" indexes" (Grubb and Wells, 1993; OECD, 1995) miss important aspects of that country's regulatory apparatus. In consequence, they accord Portugal an inappropriate rank in cross-country comparisons of the stringency of national employment protection laws.

This would be less serious were it not for the uncritical use of such ranking exercises in studies of the covariation of labor market institutions and macroeconomic outcomes. We believe this to be especially true in the case of Portugal.[10] But the problems are generic. Given the difficulty of calculating the stringency of employment protection from legal rules that are often subtle in their wording, applied differently in practice, and provide but one component of the overall regulatory framework (including collective bargaining), it is perhaps better to focus on outcomes and then work back. The present treatment, focusing on the crosscountry pattern of labor adjustment to changes in product demand, was offered in this spirit.

Results of using either a two-stage or one-stage error correction model to study the dynamics of labor demand over the last two decades in Germany, Portugal, Spain, and the 
U.K. were in accordance with (revised) our priors. Specifically, Portugal shows a very high speed of adjustment to deviations from the long-run employment-output equilibrium. In conjuction with its low employment-output elasticity, this produces a fairly rapid convergence to the long-term path. It is also confirmed in our simulation exercise that the U.K. has undoubtedly the smoothest labor adjustment mechanism of all four countries in the sample, with the maximum impact of an exogenous change in output being attained very quickly after nine quarters. In Germany by contrast the corresponding value is fifteen quarters. More importantly perhaps, its speed of adjustment would seem to have deteriorated in recent years. Spain is something of an outlier, combining a fairly rapid initial employment reaction to changes in output demand with a highly erratic long-run pattern of labor adjustment.

Exercises such as the present treatment provide insights into aspects of the practice of employment protection. Given the points of conflict with popular indicators of employment protection, the worth of the latter must be in considerable doubt. Of course, more progress in understanding the precise impact of employment protection practices awaits the proper parameterization of individual mandates, reinforcing doubts as to the efficacy of the conventional highly aggregative measures. 
APPENDIX - Manufacturing Data

Germany (West Germany)

\begin{tabular}{|l|l|l|}
\hline \multicolumn{1}{|c|}{ Variable } & Series Acronym & \multicolumn{1}{c|}{ Description } \\
\hline L - Employment & DEUEMPMF & Employment \\
\hline Y- Output & FDRIP & Industrial production \\
\hline W- Wages & FDREARN & Hourly earnings \\
\hline E - price of Energy input & FDRPPIPP & PPI of petroleum products \\
\hline INT - price of intermediate input & FDRPPISF & PPI of intermediate goods \\
\hline
\end{tabular}

Source: OECD Main Economic Indicators database (quarterly series) for the period 1977-1994; Federal Statistical Office 1994 -1997, except for the employment series which was taken from Federal Statistical Office, 1990 onward.

Spain

\begin{tabular}{|l|l|l|}
\hline \multicolumn{1}{|c|}{ Variable } & Series Acronym & \multicolumn{1}{c|}{ Description } \\
\hline L - Employment & ESPEMPIN & Employment \\
\hline Y- Output & ESPIP or MF & Industrial production \\
\hline W- Wages & ESPEARN & Hourly earnings \\
\hline PE - price of energy & ESPPPIFU & PPI of energy \\
\hline INT - price of intermediate input & ESPPPISF & PPI of intermediate goods \\
\hline
\end{tabular}

Source: OECD Main Economic Indicators database (quarterly series). The sample period is 1977:1-1997:4.The ESPEARN series is only available until 1994. It was extended into 1997 using the data contained in Encuesta de Salarios en la Industria y los Servicios.

United Kingdom

\begin{tabular}{|l|l|l|}
\hline \multicolumn{1}{|c|}{ Variable } & Series Acronym & \multicolumn{1}{c|}{ Description } \\
\hline L - Employment & GBREMPMF & Employment \\
\hline Y - Output & GBRIPMF & Industrial production \\
\hline W - Wages & GBREARN & Weekly earnings \\
\hline PE - price of energy input & GBRPPIFU & PPI of energy \\
\hline PRM - price of raw materials & GBRPPIRM & PPI of raw materials \\
\hline
\end{tabular}

Source: OECD Main Economic Indicators database (quarterly series). The sample period is 1977:1-1997:4

Portugal

\footnotetext{
The output series were drawn from Contas Nacionais Trimestrais - INE (Junho de 1998; Maio de 1992). Because the available employment series do not control for the 1983 and 1991 statistical breaks, some manipulation of the original data was required. In our procedure, the original quarterly series published by INE were adjusted by the annual series published by Pinheiro (1997) assuming the same the original quarterly shares. In addition, because manufacturing employment was available on a semi-annual basis between 1977 and 1983 , quarterly figures for this period were computed using quarterly employment indices for the manufacturing sector published by the Portuguese Ministry of Labor.

Between 1977 and 1990, manufacturing wages are given by an index of quarterly average earnings published by the Ministry of Labor. This series was discontinued in 1991. Thereafter the information pertains to negotiated wages at industry level, which is used to complete the series up to 1997. The input price of energy is given by the deflator of the energy sector and was computed from Contas Nacionais Trimestrais (valores sectoriais).
} 


\section{ENDNOTES}

[1] Blanchard and Portugal (1998) have recently argued that much hides behind an unemployment rate, and that in assessing labor market rigidities one should instead look to the scale of worker and job flows and then to unemployment duration. The present treatment is predicated on alternative tests based on the speed of adjustment of labor demand to changes in output.

[2] The principal dissenting evidence is from establishment surveys inquiring of employers the reasons, including insufficient flexibility in hiring and shedding labor, why they are not currently employing more workers (Commission, 1991). In addition, employers have been surveyed as to their perception of constraints on the management of working time and the utilization of atypical work (e.g. IOE, 1985). Such surveys produce different, and sometimes very different, country rankings from the "objective" Grubb-Wells index(es).

[3] Prior to 1975 the law did not require any concrete/objective reason for the termination of an individual contract. Firms had only to provide advance notice and a severance payment in proportion to the worker's years of service.

[4] The wages of those at the upper end of the earnings distribution do not necessarily follow collectively-bargained settlements. As a result, one observes increasing wage dispersion within Portuguese firms that is even higher than is observed in many other, more advanced industrialized nations (Cardoso, 1997).

[5] It would be preferable to work from the beginning with seasonally adjusted data and then incorporate seasonality into the labor demand model. An adequate treatment requires however an economic theory that explicitly models seasonality or an econometric strategy that incorporates seasonal dynamics directly. Examples of such treatments, applied to German labor demand, are Flaig and Steiner (1989), Belke and Göcke (1997), and Reimers (1998). Since it was not possible to obtain seasonally unadjusted series for all selected variables and countries, we applied the seasonal filter $\left(1+\mathrm{L}+\mathrm{L}^{2}+\mathrm{L}^{3}\right)$ to the original series.

[6] It can be shown that the OLS estimates are highly efficient with variances $\mathrm{O}\left(\mathrm{T}^{-2}\right)$ and consistent with an $\mathrm{O}\left(\mathrm{T}^{-1}\right)$ bias.

[7] A low value for $\lambda$ means that the OLS residuals are highly autoregressive and not stationary.

[8] The simulation using column (a) gives approximately the same results.

[9] Reimers (1998), for the sample period 1972:1-1994:7, reports a long-run output elasticity of 1.04 .

[10] Fallacious assessment of Portuguese labor laws evidently exhibits path dependence. Thus, in a recent, wide-ranging study of employment protection systems in the EU, Shömann, Rogoswski, and Kruppe (1998, p. 58) claim that "just cause dismissals include only cases of dismissals for gross misconduct of the employee." As our discussion in section 2 makes clear, this is just plain wrong. 
Table 1: Evolution of the Main Variables in Manufacturing, 1977:1 - 1997:4

\begin{tabular}{|l|l|l|l|l|}
\hline & Output & Employment & Output per worker & Real wage \\
\hline Germany & $+27 \%$ & $-23 \%$ & $+65 \%$ & $+35 \%$ \\
\hline Portugal & $+60 \%$ & $0 \%$ & $+60 \%$ & $+5 \%$ \\
\hline Spain & $+40 \%$ & $-20 \%$ & $+80 \%$ & $+50 \%$ \\
\hline U.K. & $0 \%$ & $-40 \%$ & $+70 \%$ & $+60 \%$ \\
\hline
\end{tabular}

Note: Real wages were computed using the CPI series available for each country 
Table 2: Unit Root Tests on the Levels of the Variables

\begin{tabular}{|c|c|c|c|c|c|c|c|c|c|c|c|c|c|c|c|c|}
\hline \multirow{3}{*}{ Series } & \multicolumn{4}{|c|}{ Germany } & \multicolumn{4}{|c|}{ Portugal } & \multicolumn{4}{|c|}{ Spain } & \multicolumn{4}{|l|}{ U.K. } \\
\hline & \multicolumn{4}{|c|}{ Ho: $y_{t} \sim \mathrm{I}(1)$} & \multicolumn{4}{|c|}{ Ho: $y_{t} \sim \mathrm{I}(1)$} & \multicolumn{4}{|c|}{ Ho: $y_{t} \sim I(1)$} & \multicolumn{4}{|c|}{ Ho: $\mathrm{y}_{\mathrm{t}} \sim \mathrm{I}(1)$} \\
\hline & $\mathrm{ADF}$ & $\mathrm{k}$ & $\mathrm{F}(4, \mathrm{~T})$ & $90 \%$ Interval & $\mathrm{ADF}$ & $\mathrm{k}$ & $\mathrm{F}(4, \mathrm{~T})$ & $90 \%$ Interval & $\mathrm{ADF}$ & $\mathrm{k}$ & $\mathrm{F}(4, \mathrm{~T})$ & $90 \%$ Interval & ADF & $\mathrm{k}$ & $\mathrm{F}(4, \mathrm{~T})$ & $90 \%$ Interval \\
\hline $\mathrm{L}$ & -2.17 & 12 & 1.03 & $(0.81,1.05)$ & -1.45 & 6 & 0.61 & $(0.93,1.06)$ & -2.28 & 12 & 1.21 & $(0.80,1.05)$ & -3.20 & 3 & 0.63 & $(0.65,1.03)$ \\
\hline $\bar{Y}$ & -2.98 & 11 & 0.58 & $(0.67,1.04)$ & -3.17 & 12 & 0.74 & $(0.64,1.02)$ & -2.87 & 12 & 1.04 & $(0.68,1.04)$ & -2.54 & 4 & 0.39 & $(0.78,1.04)$ \\
\hline$p / w$ & -2.27 & 9 & 0.19 & $(0.77,1.06)$ & -2.35 & 8 & 0.79 & $(0.77,1.06)$ & -3.27 & 8 & 1.15 & $(0.53,1.03)$ & -2.41 & 4 & 0.90 & $(0.77,1.05)$ \\
\hline
\end{tabular}

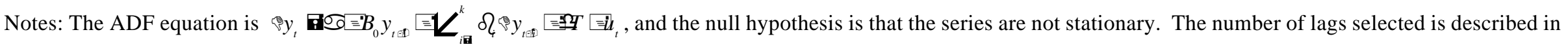

the test. The $\mathrm{F}(4, \mathrm{~T})$ statistic tests for the presence of (fourth order) serial correlation in the residuals of the ADF equation (the null is absence of autocorrelation). MacKinnon critical values for the ADF test are -4.04 and -3.45 at $1 \%$ and $5 \%$, respectively. T is the number of observations in the LM test regression. The $90 \%$ confidence interval is that for the largest autoregressive root (Stock, 1991). Definitions of the variables are given in the Appendix. $p / w$ denotes the relative input price of intermediate inputs (Germany), energy (Portugal and Spain), and raw materials (U.K.). The sample period is 1977:1-1997:4. 
Table 3: Unit Root Tests with Structural Breaks

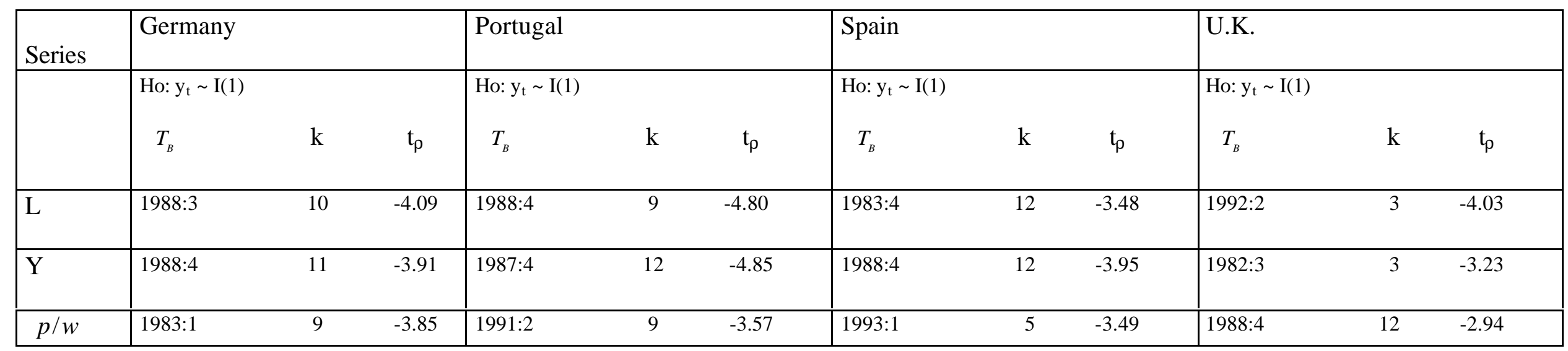

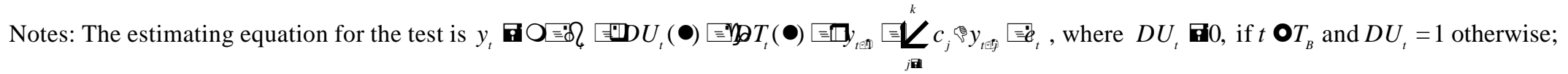

$D T_{t} \boldsymbol{\nabla} t T_{B}$, if $t \odot T_{B}$ and $D T_{t}=0$ otherwise ; and $\bullet T_{B} / T$. The model was estimated with the breakpoint $T_{B}$ ranging from $\mathrm{t}=1977: 2$ to $\mathrm{t}=1997: 3$. $T_{B}$ was chosen so as to maximize $\left|t_{\mathrm{a}}\right|$. The number of lags $\mathrm{k}$ is again determined using Perron's selection procedure. The critical values for the test are $-5.57,-5.30$, and -4.82 , at 1,5 , and $10 \%$, respectively (Zivot and Andrews, 1992, Table 4). Definitions of the variables are given in the Appendix. $p / w$ denotes the relative input price of intermediate inputs (Germany), energy (Portugal and Spain), and raw materials (U.K.). 
Table 4: First-Stage Cointegrating Regressions

\begin{tabular}{|l|l|l|l|l|}
\hline \multicolumn{1}{|c|}{ Variables } & Germany & Portugal & Spain & UK \\
\hline Constant & & & & \\
\hline trend & 12.14 & 4.33 & 4.910 & 6.14 \\
\hline Output & -0.005 & -0.005 & -0.009 & -0.011 \\
\hline$p / w$ & 0.839 & 0.396 & & 0.621 \\
\hline $\mathrm{R}^{2}$ & 0,044 & -0.034 & 0.739 & \\
\hline SER & & & -0.257 & -0.017 \\
\hline CRDW & 0.84 & 0.93 & & 0.98 \\
\hline ADF(4) & 0.43 & 0.010 & 0.88 & 0.022 \\
\hline $\mathrm{Z}_{\alpha}(\mathrm{L}=4)$ & -2.50 & 0.50 & 0.033 & 0.38 \\
\hline & $-16,797$ & -4.17 & 0.07 & -2.52 \\
\hline
\end{tabular}

Notes: SER is the standard error of the regression, CRDW is the cointegrating regression Durbin-Watson statistic, and ADF(4) is the Augmented Dickey-Fuller test with four lags. MacKinnon critical value for the ADF cointegrating test at $5 \%$ is -3.78 . The $\mathrm{Z}_{\alpha}$ test is described in Phillips and Ouliaris (1990), and performed using the residuals $\mathbb{Z}_{t}$ from the cointegrating regression to test for their stationarity. The null hypothesis is no stationarity of the residuals, that is, no cointegration of the variables. The critical values for two explanatory variables (not including the intercept and trend) at 5\% are: -29,89 (Haug, 1992, pp. 477-478, Tables 1-3). These are the small-sample critical values and they differ from the large-sample critical values reported by Perron and Ouliaris (1990). The parameter $\mathrm{L}=4$ denotes the number of estimated autocovariances included in the test (usually four for quarterly data). The definition of the variables is given in the Appendix. $p / w$ denotes the relative input price of intermediate inputs (Germany), energy (Portugal and Spain), and raw materials (U.K.). The sample period is 1977:1-1997:4. 
Table 5: Second-Stage ECM Estimation

\begin{tabular}{|c|c|c|c|c|c|}
\hline Variables & Germany & Portugal & $\begin{array}{l}\text { Spain } \\
\text { (a) }\end{array}$ & & U.K. \\
\hline Constant & $\begin{array}{l}-0.005 \\
(0.0004)\end{array}$ & $\begin{array}{c}0.0005 \\
(0.0008)\end{array}$ & \begin{tabular}{|l|}
-0.002 \\
$(0.0004)$
\end{tabular} & $\begin{array}{c}-0.002 \\
(0.0004)\end{array}$ & \begin{tabular}{|l|}
-0.003 \\
$(0.001)$
\end{tabular} \\
\hline$R E S_{t \in \mathbb{n}}$ & $\begin{array}{l}-0.051 \\
(0.014)\end{array}$ & $\begin{array}{c}-0.520 \\
(0.084)\end{array}$ & $\begin{array}{l}-0.02 \\
(0.013)\end{array}$ & & \begin{tabular}{|l|}
-0.110 \\
$(0.036)$
\end{tabular} \\
\hline$L_{t \oplus i t}$ & $\begin{array}{c}0.521 \\
(0.107)\end{array}$ & $\begin{array}{c}0.430 \\
(0.101)\end{array}$ & \begin{tabular}{|c|}
0.550 \\
$(0.109)$
\end{tabular} & $\begin{array}{c}0.575 \\
(0.107)\end{array}$ & \begin{tabular}{|c|}
0.640 \\
$(0.075)$
\end{tabular} \\
\hline$L_{t \in 12}$ & \begin{tabular}{|c|}
0.306 \\
$(0.103)$
\end{tabular} & $\begin{array}{c}0.398 \\
(0.104)\end{array}$ & $\begin{array}{c}0.245 \\
(0.100)\end{array}$ & $\begin{array}{c}0.240 \\
(0.100)\end{array}$ & \\
\hline$\zeta Y_{t}$ & \begin{tabular}{|c|}
0.083 \\
$(0.018)$ \\
\end{tabular} & & \begin{tabular}{|c|}
0.287 \\
$(0.045)$ \\
\end{tabular} & $\begin{array}{c}0.314 \\
(0.039) \\
\end{array}$ & \begin{tabular}{|c|}
0.131 \\
$(0.033)$ \\
\end{tabular} \\
\hline$Y_{t \oplus 12}$ & & $\begin{array}{c}-0.229 \\
(0.105) \\
\end{array}$ & & & \\
\hline$(p / w)_{t}$ & $\begin{array}{c}0.047 \\
(0.019)\end{array}$ & & \begin{tabular}{|l|}
-0.030 \\
$(0.011)$
\end{tabular} & $\begin{array}{l}-0.030 \\
(0.011)\end{array}$ & \\
\hline $\mathrm{R} 2$ & 0.87 & 0.54 & 0.95 & 0.94 & 0.68 \\
\hline SER & 0.0029 & 0.006 & 0.002 & 0.022 & 0.006 \\
\hline $\begin{array}{l}\mathrm{F} \\
\mathrm{LM}(4)\end{array}$ & $\begin{array}{l}2.63 \\
10.45\end{array}$ & 2.72 & $\begin{array}{l}1.71 \\
7.20\end{array}$ & $\begin{array}{l}1.49 \\
6.25\end{array}$ & 2.40 \\
\hline $\mathrm{ARCH}$ & 0.35 & 0.94 & 0.84 & 0.64 & 1.22 \\
\hline NORM & 1.33 & 1.39 & 0.67 & 1.05 & 2.31 \\
\hline RESET & 1.37 & 0.034 & $0 . .65$ & 1.33 & 0.43 \\
\hline WHITE & 0.80 & 0.58 & 0.38 & 0.37 & 0.89 \\
\hline
\end{tabular}

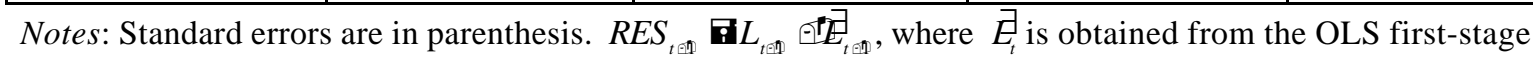
estimation. SER is the standard error of the regression, and LM(4) is the fourth order autocorrelation test. MacKinnon critical values for the $t_{E C M}$ test at $1 \%, 5 \%$, and $10 \%$ are $-4.32,-3.78$, and 3.50, respectively. ARCH is the test for autoregressive conditional heteroscedasticity, NORM is the Jarque-Bera test for the normality of the residuals, RESET is the Ramsey first-order test for functional form misspecification, and WHITE is White's test for heteroscedasticity based on the squares of the regressors. The definition of the variables is given in the Appendix. $p / w$ denotes the relative input price of intermediate inputs (Germany), energy (Portugal and Spain), and raw materials (U.K.). The sample period is 1977:1-1997:4. 
Table 6: One-Stage Unrestricted ECM Models

\begin{tabular}{|c|c|c|c|c|c|c|c|c|}
\hline \multirow{2}{*}{ Variables } & \multicolumn{2}{|c|}{ Germany } & \multicolumn{2}{|c|}{ Portugal } & \multicolumn{2}{|c|}{ Spain } & \multicolumn{2}{|c|}{ U.K. } \\
\hline & OLS & NLS & OLS & NLS & OLS & NLS & OLS & NLS \\
\hline Constant & \begin{tabular}{|l|}
0.682 \\
$(0.191$ \\
\end{tabular} & $\begin{array}{l}0.682 \\
0.191 \\
\end{array}$ & \begin{tabular}{|l|}
2.172 \\
$(0.360)$ \\
\end{tabular} & $\begin{array}{l}2.044 \\
(0.361) \\
\end{array}$ & \begin{tabular}{|l|}
-0081 \\
0.078 \\
\end{tabular} & \begin{tabular}{|l|}
-0.081 \\
$(0.078)$ \\
\end{tabular} & \begin{tabular}{|c|}
0.686 \\
$(0.219)$ \\
\end{tabular} & $\begin{array}{c}0.685 \\
(0.218) \\
\end{array}$ \\
\hline$\lambda$ & - & $\begin{array}{l}-0.060 \\
0.017 \\
\end{array}$ & - & $\begin{array}{l}-0.433 \\
(0.080)\end{array}$ & & \begin{tabular}{|l|}
-0.058 \\
$(0.018)$ \\
\end{tabular} & - & $\begin{array}{l}-0.121 \\
(0.036)\end{array}$ \\
\hline$L_{t \oplus 1}$ & $\begin{array}{l}-0.060 \\
0.017 \\
\end{array}$ & - & $\begin{array}{l}-0.462 \\
(0.081) \\
\end{array}$ & - & $\begin{array}{l}-0.058 \\
0.018 \\
\end{array}$ & & $\begin{array}{l}-0.121 \\
(0.036) \\
\end{array}$ & - \\
\hline$Y_{t \oplus 1}$ & \begin{tabular}{|l|}
0.060 \\
0.021 \\
\end{tabular} & $\begin{array}{l}1.00 \\
0.169) \\
\end{array}$ & $\begin{array}{l}0.157 \\
(0.042) \\
\end{array}$ & $\begin{array}{l}0.337 \\
(0.056)\end{array}$ & \begin{tabular}{|l|}
0.125 \\
0.036 \\
\end{tabular} & \begin{tabular}{|l|}
2.144 \\
$(0.327)$ \\
\end{tabular} & \begin{tabular}{|l|}
0.077 \\
$(0.028)$ \\
\end{tabular} & $\begin{array}{c}0.643 \\
(0.113) \\
\end{array}$ \\
\hline$(P / W)_{t \oplus \mathbb{D}}$ & \begin{tabular}{|l|}
0.010 \\
0.005 \\
\end{tabular} & $\begin{array}{l}0.160 \\
0.081 \\
\end{array}$ & $\begin{array}{l}-0.026 \\
(0.007) \\
\end{array}$ & $\begin{array}{l}-0.057 \\
(0.015) \\
\end{array}$ & $\begin{array}{l}-0.004 \\
0.004 \\
\end{array}$ & \begin{tabular}{|l|}
-0.071 \\
$(0.051)$ \\
\end{tabular} & \begin{tabular}{|l|}
0.042 \\
$(0.021)$ \\
\end{tabular} & $\begin{array}{c}0.349 \\
(0.193) \\
\end{array}$ \\
\hline trend & \begin{tabular}{|l|}
-0.00027 \\
0.00010 \\
\end{tabular} & $\begin{array}{l}-0.005 \\
0.0008 \\
\end{array}$ & $\begin{array}{l}-0.0029 \\
(0.00045) \\
\end{array}$ & $\begin{array}{l}-0.006 \\
(0.0006) \\
\end{array}$ & \begin{tabular}{|l|}
-0.0007 \\
0.0002 \\
\end{tabular} & \begin{tabular}{|l|}
-0.012 \\
$(0.0009)$ \\
\end{tabular} & \begin{tabular}{|l|}
-0.0006 \\
$(0.0005)$ \\
\end{tabular} & $\begin{array}{l}-0.0048 \\
(0.0031) \\
\end{array}$ \\
\hline$L_{t \oplus \emptyset}$ & \begin{tabular}{|l|}
0.465 \\
0.115 \\
\end{tabular} & $\begin{array}{l}0.465 \\
0.014 \\
\end{array}$ & \begin{tabular}{|l|}
0.330 \\
$(0.106)$ \\
\end{tabular} & $\begin{array}{l}0.324 \\
(0.106)\end{array}$ & \begin{tabular}{|l|}
0.331 \\
0.119 \\
\end{tabular} & \begin{tabular}{|c|}
0.331 \\
$(0.119)$ \\
\end{tabular} & \begin{tabular}{|l|}
0.471 \\
$(0.107)$ \\
\end{tabular} & $\begin{array}{c}0.471 \\
(0.107)\end{array}$ \\
\hline$L_{t \in \mathbb{Q}}$ & \begin{tabular}{|l|}
0.280 \\
0.108 \\
\end{tabular} & $\begin{array}{l}0.280 \\
0.108 \\
\end{array}$ & $\begin{array}{l}0.293 \\
(0.109) \\
\end{array}$ & $\begin{array}{l}0.281 \\
(0.109) \\
\end{array}$ & \begin{tabular}{|l|}
0.155 \\
0.100 \\
\end{tabular} & \begin{tabular}{|c|}
0.155 \\
$(0.100)$ \\
\end{tabular} & & \\
\hline$Y_{t}$ & \begin{tabular}{|l|}
0.091 \\
0.020 \\
\end{tabular} & $\begin{array}{l}0.092 \\
0.020 \\
\end{array}$ & & & \begin{tabular}{|l|}
0.307 \\
0.043 \\
\end{tabular} & \begin{tabular}{|c|}
0.307 \\
$(0.043)$ \\
\end{tabular} & \begin{tabular}{|l|}
0.142 \\
$(0.036)$ \\
\end{tabular} & $\begin{array}{c}0.142 \\
(0.036) \\
\end{array}$ \\
\hline$Y_{t \rightarrow 10}$ & & & \begin{tabular}{|l|}
-0.272 \\
$(0.116)$ \\
\end{tabular} & $\begin{array}{l}-0.252 \\
(0.116) \\
\end{array}$ & & & & \\
\hline$(p / w)_{t}$ & \begin{tabular}{|l|}
0.044 \\
0.021 \\
\end{tabular} & $\begin{array}{l}0.044 \\
0.022 \\
\end{array}$ & & & \begin{tabular}{|l|}
-0.042 \\
0.011 \\
\end{tabular} & \begin{tabular}{|l|}
-0.043 \\
$(0.011)$ \\
\end{tabular} & & \\
\hline $\mathrm{R}^{2}$ & 0.88 & 0.88 & 0.58 & & 0.95 & 0.96 & 0.71 & \\
\hline SER & 0.0029 & 0.030 & 0.006 & & 0.0023 & 0.0021 & 0.006 & \\
\hline
\end{tabular}

Notes: Standard errors are in parenthesis. Specifications for the OLS and NLS unrestricted ECM models are, respectively:

denotes output demand and input prices. All regression statistics (not reported in the table) show virtually the same behavior as in Table 5. 


\section{Table 7: Derived Long-run Relationships}

One-Stage ECM Model (OLS) One-Stage Nonlinear ECM Model (NLS) First-Stage Cointegrating Regression

\begin{tabular}{|c|c|c|c|}
\hline Germany & $L$ 屉1 $1.6 \leqq 1.0 Y \sqsubseteq 0.16(p / w)-10.0045 T$ & 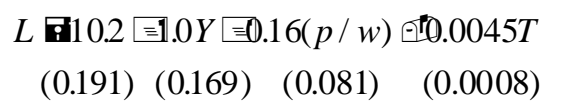 & $L$ 届1 $2.1 \sqsubseteq 0.84 Y \sqsubseteq 0.04(p / w)-0.005 T$ \\
\hline Portugal & $L$ 贯4.7 $=0.34 Y-0.06(p / w)-0.006 T$ & $\begin{array}{l}L \text { 局 } 4.7 \sqsubseteq 0.34 Y-0.06(p / w)-0.0006 T \\
\quad(0.36)(0.056) \quad(0.015)\end{array}$ & $L$ 霆 $4.3 \sqsubseteq 0.40 Y-03(p / w)-0.005 T$ \\
\hline Spain & 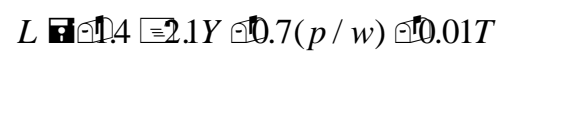 & 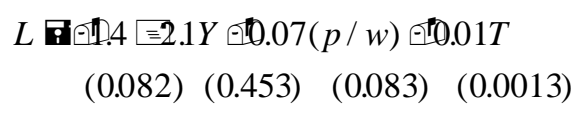 & 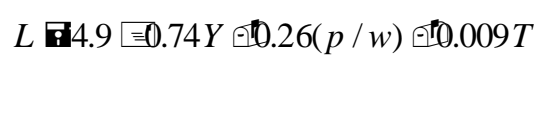 \\
\hline U.K. & $L \square 5.66 \sqsubseteq 0.64 Y \sqsubseteq 0.35(p / w)-0.005 T$ & $\begin{array}{l}L \mathbf{T} 5.7 \sqsubseteq 0.64 Y \sqsubseteq 0.35(p / w) \\
\quad(0.22)(0.11) \quad(0.19)\end{array}$ & 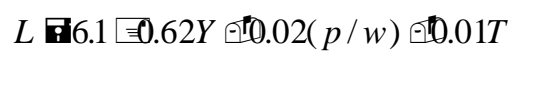 \\
\hline
\end{tabular}

Notes: Standard errors are in parenthesis. Neither the one-stage ECM nor the first-stage cointegrating regresssions provide the standard errors of the long-run estimates. 
Figure 1: Labor Demand Adjustment Following a Permanent 1 Percent Increase in Ouput

(a) Germany

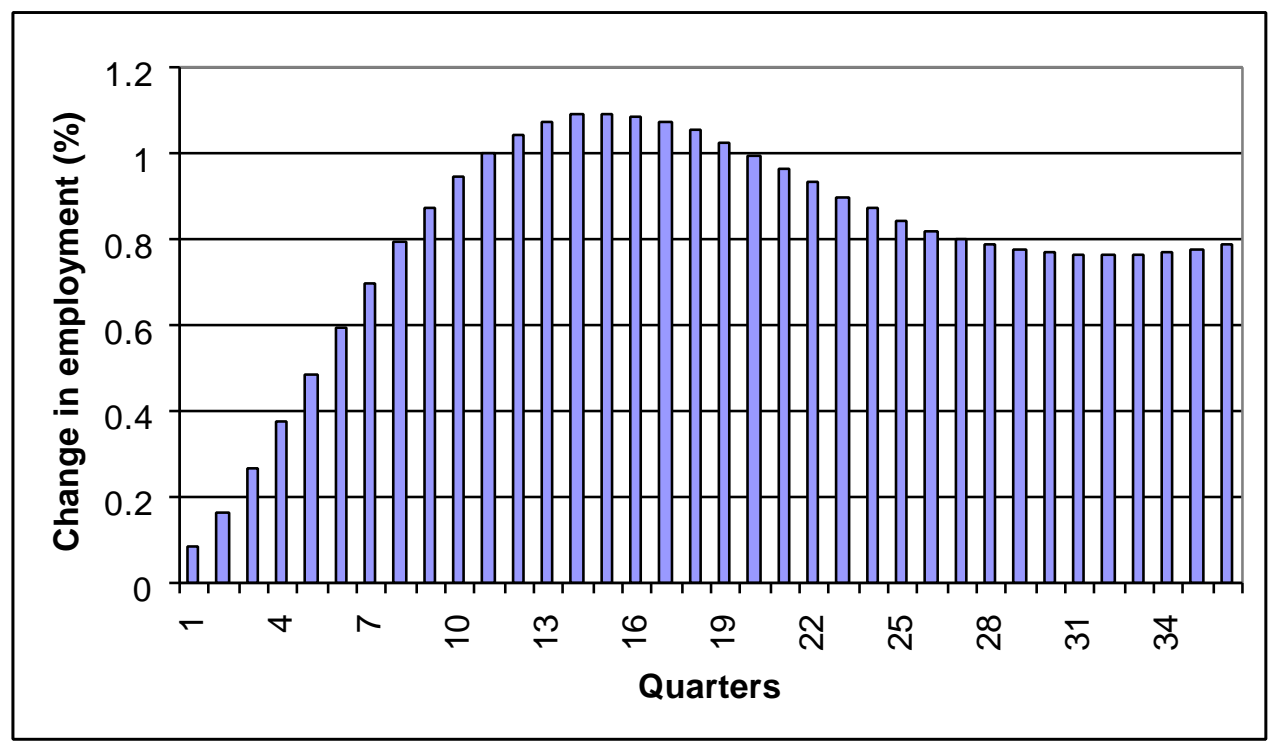

(b) Portugal

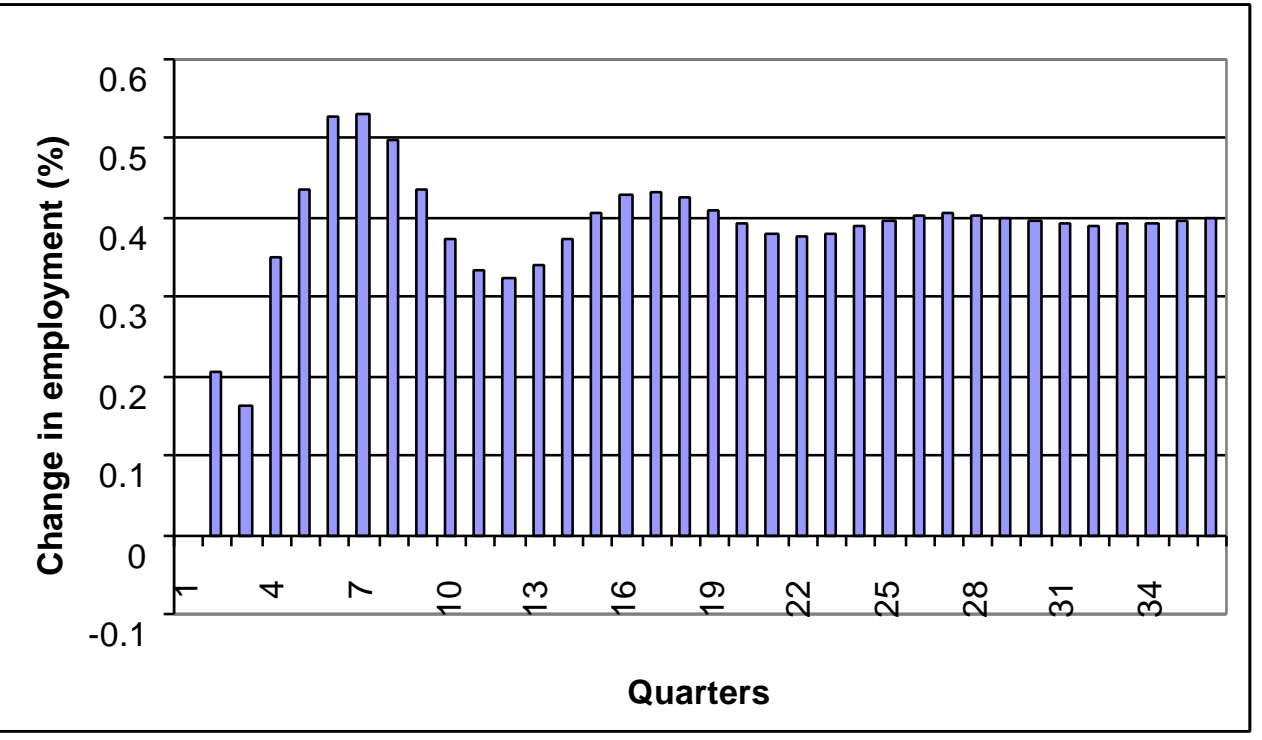


(c) Spain

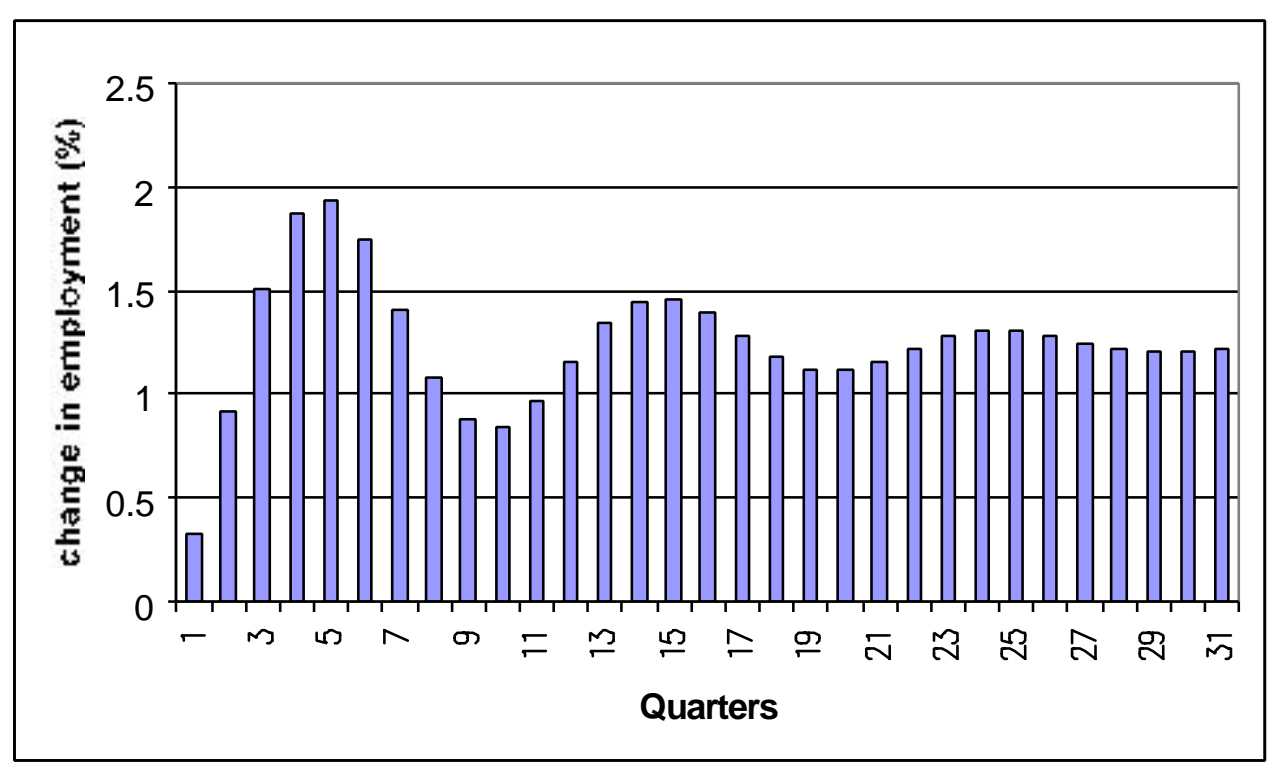

(d) United Kindgom

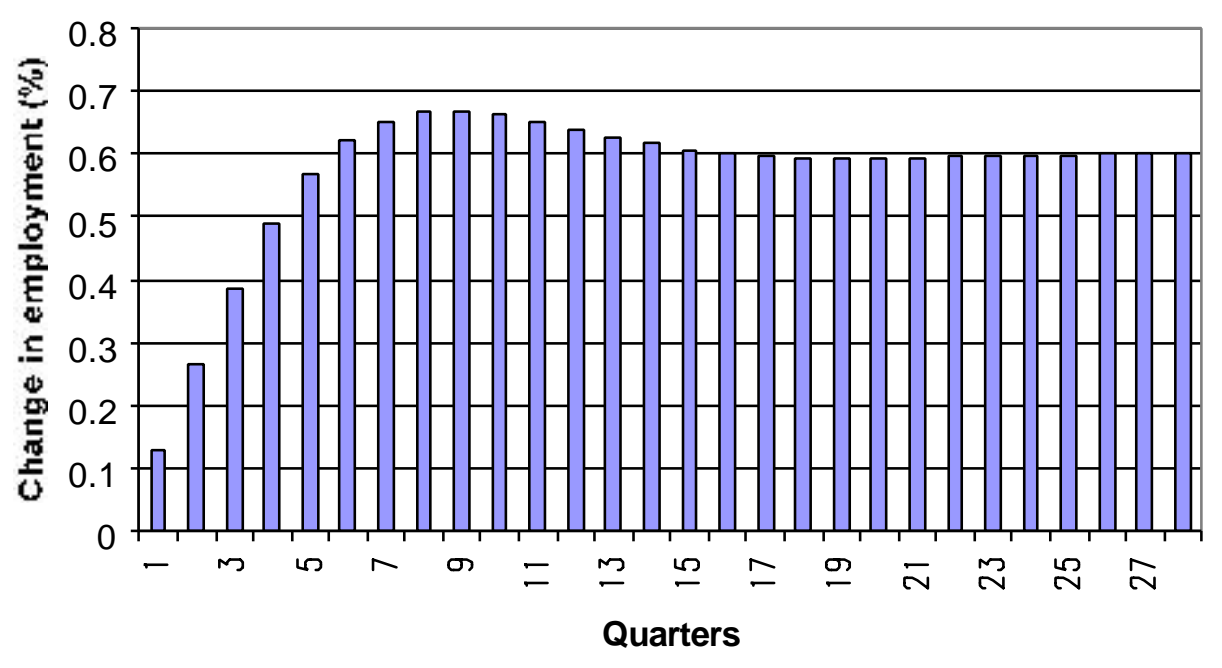




\section{REFERENCES}

Abraham, K., Houseman, S., 1993. Job security and work force adjustment: how different are U.S. and Japanese practices? In: Büchtemann, C.F. (ed.), Employment Security and Labor Market Behavior- Interdisciplinary Approaches and International Evidence. ILR Press, New York, 180-199.

Abraham, K., Houseman, S., 1994. Does employment protection inhibit labor market flexibility? In Blank, R. (ed.) Social Protection Versus Economic Flexibility: Is There a Tradeoff? University of Chicago Press, Chicago, 59-93.

Banerjee, A., Dolado, J., Mestre, R., 1992. On some simple tests for cointegration: the cost of simplicity. Unpublished paper.

Belke, A., Göcke, M., 1997. Cointegration and structural breaks in German employment: an error-correction interpretation. Jahrbücher für Nationalökonomie und Statistik 216, 129-152.

Bentolila, S., and Bertola, G., 1990. Firing costs and labour demand: how bad is Eurosclerosis? Review of Economic Studies 57, 381-402.

Bentolila, S., and Saint-Paul, G., 1994. A model of labour demand with linear adjustment costs. Labour Economics 12, 303-326.

Bertola, G., 1991. Labour turnover costs and average labour demand. Discussion Paper No. 601. Centre for Economic Performance, London.

Blanchard, O., Jimeno, J., 1995. Structural unemployment: Spain versus Portugal. American Economic Review 85, 212-218.

Blanchard, O., Portugal, P. 1998. What hides behind an unemployment rate: comparing Portuguese and U.S. unemployment. National Bureau of Economic Research Working Paper 6636.

Bover, O., Garcia-Perea, P., Portugal, P., 1997. A comparative study of the Portuguese and Spanish labour markets. Mimeo, Banco de Espana, and Banco de Portugal.

Campbell, J., Perron, P., 1991. Pitfalls and opportunities: what macroeconomists should know about unit roots. In: Blanchard, O., Fisher, S. (eds.), Macroeconomics Annual. The MIT Press, Cambridge, 140-201.

Castillo, S., Dolado, J., Jimeno, J., 1998. A tale of two neighbour economies: labour market dynamics in Spain and Portugal. CEPR Discussion Paper No. 1954.

Cardoso, A., 1997. Workers or employers: who is shaping wage inequality? Oxford Bulletin of Economics and Statistics 59, 523-547.

Commission of the European Communities, 1991. European Economy, 47.

Davidson, R., MacKinnon, J., 1993. Estimation and Inference in Econometrics, Oxford University Press, Oxford. 
Flaig, G., Steiner, V., 1989. Stability and dynamic properties of labour demand in WestGerman manufacturing. Oxford Bulletin of Economics and Statistics 51, 395-412.

Grubb, D., Wells, W., 1993. Employment regulation and patterns of work in EC countries. OECD Economic Studies 21, 7-58.

Hamermesh, D., 1993. Employment protection: theoretical implications and some U.S. evidence. In: Büchtemann, C.F. (ed.), Employment Security and Labor Market BehaviorInterdisciplinary Approaches and International Evidence. ILR Press, New York, 126-143.

Hamermesh, D., 1988. The demand for workers and hours and the effects of job security policies: theory and evidence." In Hart, A.(ed.) Employment, Unemployment and Labor Utilization, Unwin Hyman, London, 9-32.

Harvey, A., Henry, S., Peters, S., Wren-Lewis, S., 1986. Stochastic trends in dynamic regression models: an application to the employment-output equation. Economic Journal 96, 975-985.

Haug, A., 1992. Critical values for the $Z_{\mathfrak{s}}$-Phillips-Ouliaris test for cointegration. Oxford Bulletin of Economics and Statistics 54, 473-480.

Haug, A., 1996. Tests for cointegration: a Monte Carlo comparison. Journal of Econometrics $71,89-115$

Hendry, D., 1986. Econometric modelling with cointegrated variables: an overview. Oxford Bulletin of Economics and Statistics 48, 201-212.

IOE. 1985. Adapting the Labour market. International Organization of Employers, Geneva.

Kraft, K., 1993. Eurosclerosis reconsidered: employment protection and work force adjustment in West Germany. In: Büchtemann, C.F. (ed.), Employment Security and Labor Market Behavior- Interdisciplinary Approaches and International Evidence. ILR Press, New York, 297-301.

Kremers, J., Ericsson, N., Dolado, J., 1992. The power of cointegration tests. Oxford Bulletin of Economics and Statistics 54, 325-348.

Marimon, R., Zilibotti, F. 1998. 'Actual' versus 'virtual' employment in Europe: is Spain different? European Economic Review 42, 123-153.

Nickell, S., 1997. Unemployment and labour market rigidities: Europe versus North America. Journal of Economic Perspectives 11, 55-74.

OECD, 1995. The OECD Jobs Study, Part II. Organization for Economic Co-Operation, Paris.

Perron, P., 1989. The great crash, the oil price shock and the unit root hypothesis. Econometrica 57, 1361-1401.

Phillips, P.C.B., Ouliaris, S., 1990. Asymptotic properties of residual based tests for cointegration. Econometrica 58, 165-193. 
Reimers, H., 1998, Labour demand in Germany and seasonal cointegration. Unpublished paper, Fachhochschule für Technik, Wirtschaft und Gestaltung, Wismar, Germany.

Saint-Paul, G., 1995, The high unemployment trap. Quarterly Journal of Economics 110, $527-$ 550 .

Scarpetta, S., 1996. Assessing the role of labour market policies and institutional settings on unemployment: a cross-country study. OECD Economic Studies 26, 42-98.

Schömann, K., Rogowski, R, and Kruppe T., 1998. Labour Market Efficiency in the European Union. London, Routledge.

Stock, J., 1991. Confidence intervals for the largest autoregressive root in U.S. macroeconomic time series. Journal of Monetary Economics 28, 435-459.

Teixeira, P., 1998. Contratos a prazo, emprego permanente e output: uma relação de longo prazo? Estudos de Economia, 18, 211-228.

Teixeira, P., 1999. Mudança Tecnológica na Indústria Transformadora: Que Tipo de Viés Afinal? Notas Económicas 12, 40-57.

Van Audenrode, M., 1994. Short-time compensation, job security, and employment contracts: evidence from selected OECD Countries. Journal of Political Economy 102, 76-102.

Zivot, E., Andrews, D., 1992. Further evidence on the great crash, the oil-price shock, and the unit-root hypothesis. Journal of Business and Economic Statistics 10, 251-270. 


\section{Non-Technical Summary}

Economists have long searched for evidence on the effects of national employment protection laws on such labor market aggregates as employment and, especially, unemployment. Much effort has been devoted to the construction of synthetic measures of the rigidity of national employment protection systems via so-called "reputation indexes." In this study, we show that cross-country rankings derived from these indexes can be misleading by omitting important aspects of national regulatory regimes. This is unfortunate because such ranking exercises have been used uncritically in many studies of the covariation of labor market institutions and macroeconomic outcomes. Given the difficulty of assessing the stringency of employment protection from legal rules that are often subtle in the wording, applied differently in practice, and provide but one component of the overall regulatory climate (including collective bargaining), it is better to focus on outcomes and then work back. The present study, which focuses on cross-country patterns of labor adjustment to changes in product demand, is offered in this spirit. A modicum of 'corrective' institutional detail on the nature of employment in protection in Portugal is also supplied because that country has been widely alleged to be a near exemplar of a sclerotic labor market.

The results of a detailed analysis of the process of labor adjustment in Portugal - benchmarked to the experiences of Germany, Spain and the U.K. - were in accordance with our (revised) priors. Specifically, Portugal shows a very high speed of adjustment to deviations from the long-run employment-output relationship, which, taken in conjunction with its low employment-output elasticity, produces a fairly rapid convergence to the long-term equilibrium path. Our simulation exercise demonstrates that the U.K. has the smoothest labor adjustment mechanism of all four countries in the sample, such that the maximum impact of an exogenous change in output is attained very quickly (after nine quarters). In Germany, by contrast, the corresponding value is some fifteen quarters. More importantly perhaps, that country's speed of adjustment would seem to have deteriorated in recent years. The Spanish case is something of an outlier, combining a fairly rapid initial employment reaction to changes in output demand with a highly erratic long-run pattern of labor adjustment.

Exercises such as the present treatment provide insights into aspects of the practice of employment protection. Given the points of conflict with popular indicators of employment protection, the worth of the latter must be in considerable doubt - even if the experience of the U.K. matters fairly well with popular notions of its degree of labor market flexibility. More progress in understanding the precise impact of employment protection practices necessarily awaits the proper parameterization of individual mandates at the nation-state level. 